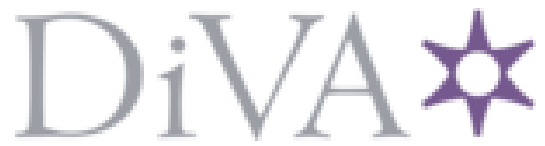

http://www.diva-portal.org

Postprint

This is the accepted version of a chapter published in The Multimedia Encyclopedia of Women in Today's World.

Citation for the original published chapter:

Davey, G., Zhao, X. (2013)

China Association of Women Entrepreneurs

In: Mary Zeiss Stange,Carol K. Oyster,Jane E. Sloan (ed.), The Multimedia

Encyclopedia of Women in Today's World (pp. 360-362). Sage Publications

N.B. When citing this work, cite the original published chapter.

Permanent link to this version:

http://urn.kb.se/resolve?urn=urn:nbn:se:oru:diva-92860 


\section{China Association of Women Entrepreneurs}

The China Association of Women Entrepreneurs (CAWE) is a nationwide nongovernment organization (NGO) supporting Chinese women entrepreneurs. It advocates the interests and perspectives of women in business and raises concerns of gender inequity. Specifically, its aims are to support entrepreneurial activities among women, for example, business development, consultancy, and training opportunities; to address issues facing women in the workplace; to promote equal opportunities and legal rights; to conduct community outreach and networking activities; and to foster international and economic cooperation between entrepreneurs in China and their counterparts in other countries.

\section{History and Structure}

The CAWE was founded in Beijing in 1985 and recently celebrated its 25th anniversary. In 2000, CAWE attained consultative status with the Economic and Social Council of the United Nations (ECOSOC). The CAWE is a group member of the All-China Women's Federation (ACWF), a leading Chinese advocacy organization for women. Because NGOs in China are tightly controlled by the government, the CAWE is also registered with government bodies such as the Ministry of Civil Affairs and the State Asset Supervision and Administration Commission of the State Council. This national and international recognition strengthens the CAWE's standing in China, as it is extremely difficult for NGOS there to receive official recognition (an overwhelming majority is unregistered).

The CAWE is governed by a senior administrative structure, including the president, vice presidents, senior officers, board of directors, council, and various committees. The organizational structure of the CAWE consists of an administration office, education and consultancy center, foreign affairs department, membership department, and public relations department.

The CAWE has more than 10,000 members. There are two membership categories: individual member, for senior and successful career women; and group member, for women employed in a company or organization that is registered with the CAWE - there are about 50 group members throughout China. The main membership criterion is a recognized achievement in Chinese business and entrepreneurship, as members usually hold senior titles such as chairperson, president, vice president, director, head of department, or manager. Membership benefits include opportunities to participate in the CAWE's activities, access to support and resources, voting rights in elections, and access to the members-only section of the CAWE's Website, a useful source of information and resources - such as information about the organization, news of its activities, membership directory and profiles, and business laws.

\section{Advocacy Efforts}

The CAWE has made progress in tackling some issues affecting Chinese women in business. Its consultancy and training services and financial support have assisted thousands of women-headed enterprises. It has also built alliances and partnerships with other associations serving women in China and internationally, and it participates in events and meetings globally. In response to gender stereotypes and the low public recognition of women leaders in China, the CAWE organizes media 
campaigns to promote the profile of women and successful women entrepreneurs as role models. Women in China have made important achievements in entrepreneurship and senior positions, and there is an increasing number of women in senior positions and private business owners, especially in urban areas. This has been accompanied by a shift of employed women from the manufacturing to service industries, from unskilled to technical personnel, and a rising educational level of women. These major changes have taken place since the 1980s and 1990s as a result of China's economic development and reforms; government efforts in promoting equality such as social policies, new employment regulations, and reform of human resource policies and techniques; growth of the private sector, including self-employment; and an emerging civil society in China.

However, there is still an urgent need to improve the status of women in Chinese society. In China, there is a cultural and historical tradition of male dominance, based on a stereotypical division of gender and social roles in which women have held devalued positions. There is prejudice against women in the business world, which mirrors the male-dominated society. For example, only a very small proportion of women are in leadership or managerial positions, despite representing a significant proportion of the workforce. The enforcement and implementation of the government's equal opportunity legislation is debatable. Based on historical and societal data, women are more likely to make career concessions in such areas as childrearing and family responsibilities than are men, a major reason women forgo careers in business. A survey conducted by the CAWE in 2002 revealed that 60 percent of women in business had the responsibility of looking after aged parents (including in-laws), and more than 33 percent of women entrepreneurs had to do all the housework.

The advocacy ability of the CAWE, like other NGOs in China, is more limited than that of its counterparts in the West. The Chinese government controls and restricts NGOs, which limits their advocacy ability. The authoritarian Chinese government discourages criticism, and civil society is suppressed. Therefore, the CAWE and other women's groups continue to encounter many obstacles. 